\title{
ANALISIS STRATEGI BAURAN PEMASARAN DALAM PENINGKATAN PENJUALAN KAPAL PADA PT. INDUSTRI KAPAL INDONESIA (PERSERO) MAKASSAR
}

\author{
Abdul Haris \\ Dosen STIE Indonesia Makassar \\ harisbima69@gmail.com
}

\begin{abstract}
abstrak
Tujuan penelitian adalah : 1) Untuk mengetahui pangsa pasar yang dikuasai PT. Industri Kapal Indonesia di Makassar. 2) Untuk mengetahui strategi pemasaran yang diterapkan PT. Industri Kapal Indonesia di Makassar.Jenis penelitian kuantitaif sebagai bahan kelengkapan informasi dalam penelitian dan dokumen-dokumen seperti laporan-laporan hasil penjualan dan laporan biaya promosi perusahaan.Metode Analisis yang digunakan adalah ; 1) Analisis strategi pemasaran : menganalisis hal-hal yang berhubungan dengan produk, harga, promosi dan tempat dan Analisis perluasan pangsa pasar. Hasil penelitian menunjukkan bahwa Strategi pemasaran dan penjualan produk kapal dapat menunjukkan bahwa strategi pemasaran penjualan yang dilakukan oleh PT. Industri Kapal Indonesia (Persero) Makassar dari tahun 2012-2014 mengalami peningkatan penjualan mencapai $74,6 \%$. Sedangkan Perluasan pangsa pasar selama 5 (lima) tahun terakhir menunjukkan bahwa dari tahun 2012 besarnya perluasan pangsa pasar yang dicapai perusahaan 59,762 $\%$, tahun 2013 besarnya 55,331\%, tahun 2014 sebesar 73,910\%, sedangkan pada tahun 2015 sebesar 78,782 \% dan pada tahun 2016 sebesar 60,478 \%. Besarnya perluasan pangsa pasar yang dicapai oleh perusahaan sangatlah tergantung pada persediaan produk kapal yang mana nantinya akan dapat memenuhi permintaan konsumen pada saat dibutuhkan
\end{abstract}

Kata Kunci : Bauran Pemasaran,Peningkatan Penjualan

\section{Pendahuluan}

Dalam era globalisasi ini pemasaran mempunyai peranan penting di dalam membangkitkan aktivitas dan stabilitas suatu perusahaan. Maka dari itu perusahaan bisa sukses bersaing dengan cara menganggap bahwa pemasaran adalah jiwa perusahaan dan tidak lagi menjadi salah satu anggota perusahaan. Oleh karena itu pemasaran harus diperhatikan dengan sunguhsungguh dalam pencapaian tujuan perusahaan di mana suatu perusahaan akan selalu berusaha untuk mencapai hasil yang lebih tinggi yang akhirnya akan menghasilkan laba secara optimal.Namun demikian perkembangan teknologi menjamin tantangan yang dihadapi suatu perusahaan yakni bagaimana memasarkan dan menghadapi persaingan yang begitu ketat dewasa ini. Dengan melihat kenyataan yang ada, maka manajer perusahaan akan dituntut untuk lebih giat bekerja sebagai upaya untuk menciptakan upaya terobosan dalam mempertahaankan pangsa pasar.

Demikian ketatanya persaingan untuk menarik konsumen maka dibutuhkan upaya yang intesif dan terarah serta kebijaksanaan dalam menetukan pasar yang ada sebagai bagian dari pemasaran yang sangat penting untuk menghadapi persaingan yang ada.

Oleh karena itu suatu perusahaan harus mampu menentukan strategi dan pemilihan pasar yang akan dituju nantinya. Maka dari itu persahaan harus mampu menciptakan peluang pasar yang tepat untuk poduk yang akan dipasarkan nantinya guna 
mencapai tujuan perluasan pangsa pasar dan menciptakan kesempatan baru dalam pemasaran produk yang akhirnya akan meningkatkan volume penjualan dan merealisasikan tujuan akhir dari suatu perusahaan dalam memperoleh laba yang maksimal.

Adapun perluasan pangsa pasar yang dilakukan oleh perusahaan masih diperlukannya upaya untuk menangani sejauh mana perusahaan menggunakan strategi pemasaran dalam meningkatkan voleme penjualan, oleh karena itu kendala yang dihadapi oleh perusahaan masih banyak, terutama peruasahaan harus mampu memperhatikan produk, tempat, harga maupun promosi yang dilakukan. Dalam hal ini perusahaan dalam melakukan perluasan pangsa pasar harus memperhatikan dan mampu menentukan strategi pemasaran yang tepat terutama mengenai beberapa hal yang penting yaitu apakah produk yang dipasarkan masih terdapat kekurangan, misalkan masih kurangannya promosi di pasaran, yang mana memberikan

\section{Tabel 1}

Analisis strategi bauran pemasaran....

Abdul haris

peluang bagi pesaing yang melakukan usaha yang sama untu mengadakan promosi secara berkesinambungan guna memperebutkan pasar.

Untuk langkah pertama perusahaan selalu mengadakan pengujian lapangan mengenai produk yang akan dipasarkan dengan jalan melakukan promosi dan pemilihan tempat yang tepat. Hal inilah penulis mecoba menganalisis beberapa masalah yang dihadapi oleh perusahaan yang nampak dari beberapa hal yang berhubungan deagan produk yang akan di pasarkan nantinya.Perluasan pangsa pasar yang sering juga disebut market share hanya salah satu dari cara yang digunakan untuk meningkatkan volume penjualan perusahaan yang mana ditinjau dari perkembangan dari tahuh ketahun. Adapun tabel di bawah ini akan memperlihatkan beberapa hal yang berhubungan dengan strategi pemasaran dalam melakukan perluasan pangsa pasar untuk perkembangan jumlah penjualan perusahaan dengan jumlah penjualan industri

Data Volume Penjualan Kapal Pada Pt. Industri Kapal Indonesia (Persero) Makassar Tahun 2012-2016

\begin{tabular}{ccc}
\hline \multirow{2}{*}{ Tahun } & \multicolumn{2}{c}{ Volume penjualan } \\
& $\begin{array}{c}\text { Penjualan perusahaan di } \\
\text { Makassar }\end{array}$ & Penjualan industri keseluluhan \\
2012 & 2 unit & 4 unit \\
2013 & 3 unit & 6 unit \\
2014 & 5 unit & 7 unit \\
2015 & 4 unit & 5 unit \\
2016 & 7 unit & 12 unit \\
\hline
\end{tabular}

Sumber : PT. Industri Kapal Indonesia di Makassar

Berdasarkan tabel 1 memperlihatkan adanya penjulan perusahaan pada tahun 2013 meningkat sebesar 3 unit dengan penjualan industri meningkat sebesar 6 unit. Pada tahun 2013 yang mana pada saat itu permintaan semakin meningkat di Makassar, sehingga adanya persaiangan di beberapa perusahaan yang melakukan kegiatan yang sama dalam penjualan kapal. Penurunan penjualan perusahaan pada tahun 2016 sebesar 4 unit dengan penjualan industri sebesar 5 unit. Hal ini diakibatkan oleh kurangnya permintaan pasar sebagai dampak dari besarnya biaya produksi sebagai salah satu pengaruh dari perubahan nilai tukar uang. Dalam hal ini terdapat adanya perubahaan yang besar terhadap penjulan industri yang nilainya sudah cukup bagus terutama pada penjualan indutri yang lebih besar dari penjulan 
perusahaan yang diperoleh pada tahun 2013 dan 2015, dalam melakukan perluasan pasar secara intensif melalui strategi pemasaran yang dilakukan oleh perusahaan. Agar tidak terjadi penurunan dalam penjualan perusahaan maupun penjualan industri maka perusahaan harus melakukan langkah yang tepat dalam meningkatkan volume penjualan.

Perluasan pangsa pasar yang telah dijalankan perusahaan selalu berorientasi pada perluasan pangsa pasar yang mana kegiatan ini harus dijalankan pada beberapa hal yang berhubungan dengan strategi pemasaran yang tepat, hal ini harus diusahakan oleh perusahaan karena beberapa hal yang berhubungan dengan produk yang dijalankan harus tepat pada sasaran yang diinginkan. Dalam melakukan pemasaran

\section{METODE PENELITIAN}

Daerah dan Waktu Penelitian

Penelitian ini diadakan di PT. Industri Kapal Indonesia di Makassar. Waktu penelitian Tahun 2017.

\section{Metode Pengumpulan Data}

Untuk memperoleh informasi yang akurat dalam penelitian ini, penulis menggunakan beberapa metode pengumpulan data yang relevan untuk memecahkan atau menganalisa masalah tersebut dengan metode sebagai berikut :

1. Metode observasi (pengamatan) yaitu dengan mengadakan pengamatan secara langsung di lokasi penelitian kepada pimpinan dan bagian yang terkait.

2. Metode interview (wawancara) yaitu dengan wawancara beberapa responden terkait dengan penelitian, termasuk pimpinan perusahaan dan kepala bagian serta orang-orang yang diberi wewenang untuk memberikan informasi sehubungan dengan penelitian.

\section{Jenis dan Sumber Data}

Jenis dan sumber data kualitatif dan kuantitaif sebagai bahan kelengkapan informasi dalam penelitian.
Analisis strategi bauran pemasaran....

Abdul haris perusahaan tidaklah menggunakan caracara yang masih tradisional yaitu dengan cara melakukan penjualan saja yang mana penjualan ini harus berfokus pada penjualan semata saja atau hanya mendapatkan laba, tetapi harus diusahakan pada beberapa hal yang berhubungan deangan keperecayaan konsumen pada produk yang akan dipasarkan.

\section{Tujuan Penelitian}

Tujuan penelitian adalah:

1. Untuk mengetahui pangsa pasar yang dikuasai PT. Industri Kapal Indonesia di Makassar.

2. Untuk mengetahui strategi pemasaran yang diterapkan PT. Industri Kapal Indonesia di Makassar.

Sumber data yang sifatnya dapat dikategorikan sebagai berikut :

1. Data Kualitatif

Yaitu data yang bersumber dari dalam perusahaan berupa hasil pengamatan, wawancara terhadap pimpinan dan beberapa karyawan yang terkait.

2. Data Kuantitatif

Yaitu data diperoleh dari bahan tertulis dari dokumen-dokumen seperti laporan-laporan hasil penjualan dan laporan biaya promosi perusahaan.

\section{Metode Analisis}

Untuk mengetahui sejauh mana kebenaran hipotesis yang telah dikemukakan sebelumnya, maka metode yang digakan adalah:

a. Analisis strategi pemasaran : mengenalisis hal-hal yang berhubungan dengan produk, harga, promosi dan tempat.

b. Analisis perluasan pangsa pasar yaitu suatu analisis yang berfungsi untuk dapat melihat dan menentukan perluasan pangsa pasar yang dicapai oleh perusahaan dengan rumus sebagai berikut: 
RUMUS :

$\mathbf{M S}=\frac{\sum P p}{\sum P i} \times 100 \%$

Dimana :

MS : Perluasan pangsa pasar

$\mathrm{Pp}$ : Penjualan Perusahaan

$\mathrm{Pi}$ : Penjualan Industri

Adapun defenisi operasional yang di gunakan adalah sebagai berikut :

a. Analisis adalah penelusuran kesempatan atau landasan atas sumber analisis melibatkan pemecahan keseluruhan keadaan bagian-bagian untuk mengetahui sifat, fungsi dan saling berhubungan antara bagian tersebut.

b. Pengembangan intensif : pengembangan yang dilakukan secara bertahap dan memerlukan waktu cukup lama dalam melakukan pengembangan produk tersebut.

c. Pengembangan produk merupakan kelanjutan produk yang sudah jadi dengan menitiberatkan pada biaya yang digunakan dalam menghasilkan produk yang baru bagi perusahaan.

d. Kesempatan pengembangan adalah bagaimana perusahaan menggunakan moment yang dapat

\section{HASIL PENELITIAN DAN \\ PEMBAHASAN}

\section{Analisis Strategi Perusahaan}

Untuk mempertahankan kelangsungan hidup perusahaan maka perusahaan itu harus mengadakan peningkatan penjualan agar mampu bersaing di pasar sehingga dapat meningkatkan market share perusahaan, yang secara tidak langsung memberikan posisi yang sangat baik bagi perusahan dalam melakukan persaingan dengan perusahaan sejenis.penjualan industry secara keseluruhan dapat pula berpengaruh pada penjualan perusahaan
Analisis strategi bauran pemasaran....

Abdul haris

dalam mengembangkan produknya agar dalam memasarkan produknya tidak sia-sia.

e. Strategi pemasaran merupakan inti kegiatan pemasaran yang dapat dikontrol untuk dapat mempengaruhi pasar yang menjadi sasaran .

f. Pangsa pasar adalah bagaimana perusahaan mengatur meningkatkan antara penjualan perusahaan dan penjualan industri serta saling menyesuaikan kegiatan.

g. Perluasan pangsa pasar merupakan kegiatan dalam memperluas pasar industri melalui perusahaan secara kontinyu tanpa mengabaikan keuntungan yang didapatkan dari perusahaan.

h. Pengembangan pasar industri adalah bagaimana perusahaan dalam mengembangkan produknya harus dapat lebih memperhatikan pasar industri yang dapat dalam memproduksi produk yang nantinya di gunakan oleh konsumen.

i. Pemasaran adalah salah satu dari bagian-bagian pokok yang dilakukan oleh para pengusah dalam usaanya untuk mempertahankan kelangsungan hidupnya untuk berkembang dan mendapatkan laba.

khususnya PT. IKI (Indutri Kapal Indonesia) Persero Makassar.

Perbandingan antara penjualan perusahaan di Makassar dengan penjualan industri secara keseluruhan (cabang PT. IKI Makassar dan PT. IKI cabang Bitung yang merupakan anak perusahaan). Oleh karena itu market share perusahaan harus lebih di perhatikan agar lebih terarah dalam melakukan penjualan dan peningkatan pangsa pasar dengan lebih mengutamakan penjualan melalui berbagai promosi untuk mengetahui seberapa besar pengaruh market share terhadap perusahaan yang dapat dilihat dari berapa banyak jumlah produk ( kapal ) yang telah terjual d pasaran, dan 
mengetahui seberapa besar penggunaan dana yang telah digunakan/dikeluarkan perusahaan dalam membiayai bahan baku dan tenaga kerjanya. Sehingga hal inilah perusahaan harus selalu mengutamakan adanya tenaga pemasaran dalam melakukan penjualan. Adapun pemasaran sangatlah besar pengaruhnya dalam kelangsungan hidup perusahaan terutama peningkatan penjualan industri yang meningkat dan secara tidak langsung meningkatkan pula volume penjualan perusahaan, yang mana peningkatan penjualan produk ( kapal ) dari industri merupakan hasil dari penjualan produk ( kapal ) perusahaan yang lebih mengutamakan kemampuan menguasai pasar. Untuk itulah perusahaan harus selalu mengutamakan penjualan melalui berbaga terobosan dalam pasar terutama dalam memperkenalkan merek dari sebuah produk terutama produk kapal PT. Indutri Kapal Indonesia ( Persero ) Makassar dalam menjalankan usahanya yang menitiberatkan pada keuntungan penjualan perusahaan nantinya, hal ini disebabkan penjualan industri lebih mengutamakan keuntungan dan penjualan perusahaan lebih mengutamakan kualitas yang telah teruji.

\section{Analisis Strategi Marketing Mix}

Dalam menganalisis data tersebut akan diutarakan aspek marketing mix yang digunakan oleh PT. Industri Kapal Indonesia ( Persero ) Makassar. Oleh karena itu perusahaan yang bergerak dibidang penjualan produk kapal di dominasi oleh adanya penjualan secara langsung dengan menggunakan strategi pemasaran. Dalam hal ini strategi pemasaran sebagai acuan dalam menentukan seberapa besar keuntungan yang di dapat dari penjualan kapal tersebut. Adapun marketing mix yang akan di jelaskan dibawah ini :

\section{Produk}

Produk merupakan objek utama dari pemasaran dan juga produk yang
Analisis strategi bauran pemasaran.... Abdul haris merupakan kombinasi dari barang dan jasa yang perusahaan tawarkan kepada konsumen. Adapun produk yang di tawarkan oleh PT. Industri Kapal Indonesia (Persero ) Makassar pada garis besarnya dikenal 5 ( lima ) jenis produk yang di tawarkan beserta harganya yaitu :

1. Kapal Roro 500 GRT

:Rp. 20.447.000.000,-

2. Ferry Roro 300 GRT

:Rp. 16.550.000.000,-

3. Ferry Roro 200 GRT

: Rp. 14.790.000.000,-

4. Tongkang Type Panamax : Rp. 21.075.000.000,-

5. BP2P Kapal Latih : Rp. 13.375.000.000,-

Dalam suatu produk tergantung pada fungsi produk tersebut dan factor yang lain diharapkan oleh konsumen tersebut yang sering produk plus pelayanan, pilihan yang ada (option), gaya (stile), merek, macam (produck item), jaminan dan sports post (suku cadang) dan pemeliharaan (service).

\section{Harga jual}

Sesuai dengan stratifikasi sosial calon konsumen ditetapkan 3 (tiga) struktur yang ditawarkan pada PT. Industri Kapal Indonesia (Persero) Makassar yaitu :

1. Calon konsumen pada daerah kepulauan kecil ditawarkan jenis kapal Ferry Roro 200 - 500 GRT.

2. Calon konsumen yang menggunakan kapal sebagai sarana angkutan barang $d$ tawarkan jenis kapal Tongkang Type Panamax.

3. Calon konsumen yang prioritas kepemilikan kapal sebagai alat praktek di tawarkan jenis kapal BP2P Kapal Latih

Produk kapal yang ditawarkan oleh PT. Industri Kapal Indonesia (Persero) di Makassar pada garis besarnya dikenal dengan dua macaam 
jenis peruntukan bagi pemasaran yaitu sebagai alat transportasi pengangkutan dan sebagai alat latih bagi lembaga yang mempelajari mengenai perkapalan.

\section{Distibusi}

\begin{abstract}
untuk mencapai tujuan dan sasaran perusahaan di bidang pemasaran, setiap perusahaan melakukan kegiatan dan berupaya untuk memperlancar arus barang dan jasa dari produsen ke konsumen maka PT. Industri Kapal Indonesia (persero) membuka satu cabang atau show room di Bitung. Pentingnya saluran distribusi bagi perusahaan merupekan satu hal mutlak untuk diprhatikan agar permintaan konsumen dapat dilayani dengan cepat. Distribusi barang yang cepat dapat juga menjadikan pelanggan lebih puas dalam menentukan hasil dari keinginannya. Sebagai baha dalam mencapai tujuan perusahaan agar dapat mencapai keinginan dari konsumen.
\end{abstract}

\section{Promosi}

Promosi merupakan susatu proses kegiatan yang dilakukan oleh perusahaan atau produsen untuk mengadakan komunikasi dangan konsumen atau pasar.Lebih dari itu, promosi merupakan alat untuk mempengaruhi konsumen sekaligus alat untuk mengatasi persaingan pasar. Kegiatan promosi yang dilakukan sejalan dengan rencana pemasaran secara keseluruhan serta diharapkan akan berperan secara aktif dalam meningkatkan perluasan pangsa pasar. Suatu pruduk apapun bermanfaat apabila dapat dikenal baik oleh konsumen, maka produk tersebut akan lebih mudah dalam pemasarannya.

\section{Analisis Strategi Pemasaran}

Dalam memahami segmentasi pasar terlebih dahulu penulis memberikan gambaran tentang strategi pemasaran yang penulis teliti pada PT. Industri Kapal Indonesia (Persero)
Analisis strategi bauran pemasaran....

Abdul haris

Makassar, terutama mengenai Produk, Harga, Distribusi dan Promosi.

Dalam strategi pemasaran pada dasarnya membaagi pasar atas beberapa kelompok yang mana kelompok tersebut merupakan bagian yang tidak dapat dipisahkan antara satu dengan yang lain. Untuk lebih jelasnya strategi pemasaran yang berfokus pada produk yang telah $\mathrm{d}$ jelaskan di atas akan diuraikan di bawah ini:

\section{Produk}

Adapun yang dimaksud dengn produk adalah sesuatu yang nyata dan nampak baik dalam bentuk fisinya maupun wujudnya. Oleh karena itu penulis mengutarakan produk sebagai salah satu aspek penelitian karena dalam bagian strategi pemasaran yang penulis dapatkan bahwa perusahaan PT. Industri Kapal Indonesia (Persero) Makassar memiliki berbagai type produk yang mana produk inilah yang besar pengaruhnya terhadap perusahaan.

\section{Harga}

Dalam menjalankan perusahaan ada beberapa hal yang perlu diketahui yaitu bagaimana perusahaan dalam menjalankan fungsinya terutama sebagai perusahaan industri perlu diketahui bahwa penetapan harga sangatlah mendominasi dari tingkat penjualan. Hal inilah yang mempengaruhi bahwa harga yang telah ditetapkan oleh perusahaan belumlah tepat karena dalam penetapan harga selalu dipengaruhi adanya penetapan faktor penetapan harga oleh pemerintah, yang mana harga di pasaran masih berfluktuasi baik dari segi bidang penjualannya maupun penetapan harganya secara langsung. Sebagai tindak lanjut dari penetapan harga yang bervariasi maka dari itulah perusahaan harus memperhitungkan seberapa besar pemberian industri terhadap perusahaan dalam mengambil resiko nantinya, agar dalam penetapannya dapat lebih dikendalikan lagi. 
Seperti yang diketahui bahwa dengan semakin berkembangnya dunia usaha pada umumnya di dunia industri dan khususnya di Indonesia dewasa ini maka tujuan daripada manajemen perusahaan adalah mempertahankan atau mendapatkan keuntungan yang optimal, agar tujuan tersebut dapat dicapai maka diperlukan adanya manajemen yang efisien yang msmpu menciptakan suatu rangkaian kerjasama yang trorganisir dengan baik antara masing-masing fungsi yang ada dalam perusahaan.

$$
\text { Kini semakin banyak }
$$

perusahaan yang bermunculan yang menyebabkan fungsi pemasaran semakin memegang peranan penting dalam menghadapi pasar di mana pemasaran mempunyai peranan yang cukup besar untuk menunjang pencapaian tujuan perusahaan.bahkan dapat dikatakan bahwa pemasaran memiliki dampak terhadap strategi pemasaran dan kemajuan perusahaan.Dalam hubungannya dengan uraian di atas, maka untuk dapat meningkatkan perluasan pangsa pasar perusahaan perlu dilakukan strategi pemasaran di mana dengan strategi pemasaran dapat meningkatkan perluasan pangsa pasar.

Adapun tujuan atau sasaran dan penetapan strategi pemasaran yang dilakukan oleh PT. Industri Kapal Indonesia (Persero) Makassar antara lain:

1. Untuk meningkatkan perluasan pangsa pasar perusahaan sehingga dapat menunjang aktivitas perusahaan dan memperoleh laba yang maksimal.

2. Untuk dapat mengatasi tingkat persaingan yang ketat dalam pemasaran.
Analisis strategi bauran pemasaran....

Abdul haris

Adapun strategi pemasaran yang dijalankan oleh PT. Industri Kapal Indonesia (Persero) Makassar yaitu dengan menggunakan strategi pemasaran langsung yakni dengan cara demikian masyarakat atau konsumen dapat memperimbangkan harga yang ditawarkan oleh perusahaan dari tingkat kemampuan konsumen itu sendiri.Stategi pemasaran ini merupakan proses menyeluruh, di mana perusahaan tersebut harus memperhatikan pembelian dari masing-masing segmen atau dengan kata lain bahwa usahanya perlu memperhatikan kemampuan/daya beli masyarakat.Dengan menjalankan strategi pemasaran maka PT. Industri Kapal Indonesia (Persero) Makassar dapat mencapai target yang diinginkan dengan secara otomatis penjualannya dapat meningkat dari tahun ke tahun sehingga adanya perubahan penjualan dari penjualan perusahaan nantinya.

Adapun tabel di bawah ini memperlihatkan seberapa banyak peminat dari produk kapal yang dihasilkan ditinjau dari segi bentuk/model kapal dan pelayanan purna jualnya, sehingga dengan demikian dapat pula kita lihat adanya beberapa peningkatan dari penjualan industri yang dapat dilihat dari seberapa besar peningakatan atau penurunan yang disebabkan oleh adanya fluktuasi dari penjualan kapal dari tahun ke tahun. Untuk itulah dapat dilihat hal ini dapat dicermati dari beberapa aspek penting mengenaipenjualan perusahaan di bawah ini sehingga peningkatan dari tahun ketahun maka itu penulis dapat memberikan gambaran mengenai penjualan industri dari tahun ketahun tersebut di bawah ini: 


\section{Sentralisasi volume 7 No ( 1): 43-56 2018}

Analisis strategi bauran pemasaran....

Tabel. 2

Abdul haris

Jumlah Penjualan Pt. Indutri Kapal Indonesia (Persero) Secara Keseluruhan

Tahun 2012-2016

Penjualan Industri Keseluruhan

Tahun

Kapal (Unit)

Total Penjualan (Rp)

2012

2013

2014

2015

2016
4

6

7

5

12
66.922 .000 .000

111.996.000.000

120.124.000.000

69.705 .000 .000

221.068 .000 .000

Sumber Data : PT. Industri Kapal Indonesia (Persero)

Keterangan :

Tahun 2012:

2 unit Kapal Roro 300 GR

1 unit Kapal Roro 500 GRT

1 unit Kapal Latih

Total

Tahun 2013:

1 unit Tongkang Type Panamax : Rp. 21.075.000.000

3 unit Kapal Roro 500 GRT

2 unit Kapal Roro 200 GRT

Total

Tahun 2014:

2 unit Kapal Roro 200 GRT

3 unit Kapal Roro 300 GRT

2 unit Kapal Roro 500 GRT

Total

Tahun 2015

2 unit Kapal Roro 200 GRT

3 unit Kapal Latih

Total

Tahun 2016

4 unit Kapal Roro 500 GRT

3 unit Tongkang Typr Panamax

2 unit Kapal Roro 300 GRT

2 unit Kapal Roro 200 GRT

1 unit Kapal Latih

Total
:Rp. 33.100 .000 .000

:Rp. 20.447.000.000

:Rp. 13.375 .000 .000

Rp. 66.922.000.000

:Rp. $\quad 61.341 .000 .000$

: Rp. 29.580 .000 .000

Rp. 111.996.000.000

:Rp. 29.580.000.000

:Rp. 49.650.000.000

:Rp. 40.894.000.000

Rp. 120.124.000.000

:Rp. 29.580.000.000

: Rp. 40.125.000.000

:Rp. 81.788.000.000

: Rp. 63.225.000.000

:Rp. 33.100 .000 .000

:Rp. 29.580.000.000

:Rp. 13.375.000.000

Rp. 221.068.000.000 
Dari data strategi pemasaran, penjualan kapal di atas nmaka dapat diuraikan sebagai berikut :

1. Tahun 2012 penjualan industri mengalami penurunan sebesar 4 (empat) unit sehingga perolehan dana industri menjadi Rp. 66.922.000.000, hal ini di sebabkan masih perusahaan masih belum mengadakan promosi secara menyeluruh.

2. Tahun 2013 penjualan industri mengalami kenaikan sebesar 6 (enam) unit sehingga perlohan dana industri menjadi Rp. 111.996.000.000, di mana penjualan dari perusahaan meningkat akibat pengaruh dari perbaikan promosi yang telah dilakukan perusahaan.

3. Tahun 2014 penjualan industri terus meningkat dari penjualan kapal jenis Roro 300 GRT yang menambah dana industri menjadi Rp. 120.124.000.000, ini diperoleh dari semakin baiknya promosi dan semakin dikenalnya produk dari perusahaan beserta peningkatan produksi dari cabang perusahaan.

4. Tahun 2015 penjualan industri mengalami penurunan menjadi 5 (lima) unit akibat kurangnya permintaaan pasar oleh karena peningkatan biaya produksi sebagai salah satu pengaruh perubahan nilai tukar uang. Hal ini mengakibatkan pendapan dana industry berkurang menjadi Rp. 69.705.000.000 .

5. Tahun 2016 penjualan industri kembali stabil dan mengalami kenaikan yang cukup pesat menjadi 12 (dua belas) unit dengan pendapatan dana industri sebesar Rp. 221.068.000.000, hal ini bias terjadi kerena kemampuan manajemen perusahaan dalam memperbaiki mengelola promosi dan pemasaran dengan baik.
Analisis strategi bauran pemasaran.... Abdul haris Dari hasil data di atas maka dapat disimpulkan bahwa pada tahun 20132014 penjualan mengalami kenaikan hal ini disebabkan oleh permitaan dan penggunaan transportasi penyebrangan laut semakin meningkat, namun pada tahun 2015 terjadi penurunan akibat peningkatan biaya produksi yang juga mempengaruhi permintaan pasar. Lain halnya pada tahun 2016 penjualan industri meningkat menjadi 12 (dua belas) unit yang mana bisa ditinjau dari pendapatan dana industri sebesar $\mathrm{Rp}$. 221.068.000.000, hal ini dikarenakan kemanpuan bersaing perusahaan dalam penawaran harga dan kebutuhan konsumen dalam peningkatan transportasi laut yang sangat besar yang menjadikan transportasi laut menjadi pilihan dan prioritas utama dalam melakukan perjalanan dan perdagangan.

Dalam hal ini PT. Industri Kapal Indonesia (Persero) masih merasa perlu untuk melakukan pembinaan secara berangsur-angsur yang mana hal ini akan meningkatkan volume penjualan sebagai hasil pembelajaran dari ketinggalan perusahaan maupun kemajuan perusahaan terhadap perusahaan saingan dalam meningkatkan pangsa pasar sebagai target utama dalam penelusuran perkembangan perusahaan.Untuk lebih jelasnya pada table 2 berikut penulis menyajikan seberapa besar penjualan produk kapal pada PT. Industri Kapal Indonesia (Persero) Makassar dan seberapa jauh penjualan yang dicapai selama 5 (lima) tahun terakhir.

Adapun data yang diperlihatkan dari penjualan perusahaan dapat dilihat adanya penggunaan pegawai atau karyawan yang digunakan sebanyak 340 orang yang mana hal tersebut temasuk dalam biaya produksi perusahaan dan hasil dari penjualan perusahaan. Adapun hasil penjualan dan pendapatan dari perusahaan PT. Industri Kapal Indonesia (Persero) Makassar dapat dilihat pada table berikut ini : 


\section{Sentralisasi volume 7 No ( 1): 43-56 2018}

Analisis strategi bauran pemasaran....

Tabel 3

Abdul haris

Jumlah Penjualan Perusahaan Pada Pt. Industri Kapal Indonesia (Persero) Di

Makassar Tahun 2012 - 2016

$\begin{array}{ccc}\text { Tahun } & \text { Kapal (unit) } & \begin{array}{c}\text { Penjualan perusahaan } \\ \text { Total Penjualan (Rp) }\end{array} \\ 2012 & 2 & 36.997 .000 .000 \\ 2013 & 3 & 61.969 .000 .000 \\ 2014 & 5 & 88.784 .000 .000 \\ 2015 & 4 & 54.915 .000 .000 \\ 2016 & 7 & 113.699 .000 .000\end{array}$

Sumber : PT. Industri Kapal Indonesia (Persero) Makassar

Keterangan :

Tahun 2012

1 unit Kapal Roro 500 GRT

1 unit Kapal Roro 300 GRT

Total

Tahun 2013

1 unit Tongkang Type Panamax

2 unit Kapal Roro 500 GRT

Total

Tahun 2014

2 unit Kapal Roro 500 GRT

2 unit Kapal Roro 300 GRT

1 unit Kapal Roro 200 GRT

Total

Tahun 2015

1 unit Kapal Roro 200 GRT

3 unit Kapal Latih

Total

Tahun 2016

2 unit Kapal Roro 500 GRT

3 unit Tongkang Type Panamax

2 unit Kapal Roro 200 GRT

Total

Berdasarkan data di atas (Tabel 3), maka dapat disimpulkan bahwa pada tahun 2012 penjualan mencapai 2 (dua) unit kapal, yang mana pada tahun 2013 mengalami kenaikan sebesar 3 (tiga) unit kapal dan begitupun pada tahun berikutnya 2014 mengalami kenaikan sebesar 5 (lima) unit. Hal ini disebabkan oleh karena pada tahun-tahun tersebut terjadi perubahan pada system manajemen perusahaan berupa tidak diberlakukannya lagi system konvensional, dan perbaikan strategi pemasaran termasuk system promosi yang digunakan di dalamnya. Pada

$$
\begin{aligned}
& \text { :Rp. 20.447.000.000 } \\
& \text { : Rp. 16.550.000.000 } \\
& \text { :Rp. 36.997.000.000 } \\
& \text { :Rp. 21.075.000.000 } \\
& \text { :Rp. } 40.894 .000 .000 \\
& \text { :Rp. 61.969.000.000 } \\
& \text { :Rp. } 40.894 .000 .000 \\
& \text { :Rp. } 33.100 .000 .000 \\
& \text { :Rp. } 14.790 .000 .000 \\
& \text { :Rp. 88.784.000.000 } \\
& \text { :Rp. } 14.790 .000 .000 \\
& \text { :Rp. 40.125.000.000 } \\
& \text { :Rp. 54.915.000.000 } \\
& \text { :Rp. 40.894.000.000 } \\
& \text { :Rp. } \quad 62.225 .000 .000 \\
& \text { :Rp. 29.580.000.000 } \\
& \text { :Rp. 133.699.000.000 }
\end{aligned}
$$

tahun 2015 perusahaan mengalami penurunan penjualan sebesar 5 (lima) unit, hal ini disebabkan dengan dibukanya peluang bagi perusahaan yang bergerak dalam bidang yang sama sehingga membuka peluang persaingan dalam produksi kapal. Selain itu faktor kenaikan harga bahan baku serta naik turunnya nilai mata uang ikut serta mempengaruhi turunnya penjualan dan minat beli konsumen. Namun pada tahun berikutnya (2016) perusahaan mampu bangkit dengan mengadakan beberapa maneuver dalam memperkenalkan dan menawarkan 

langsung memberikan dampak positf yaitu peningkatan produksi dan penjualan.

Dan untuk mengetahui strategi perkapalan dapat pula dilihat dengan adanya perkembangan dari tahun ke tahun maupun penjualan dalam bentuk rupiah, hal ini untuk mengetahui seberapa besar pengaruhnya nanti dalam menganalisis antara strategi pemasaran dengan perluasan pangsa pasar, yang produk di pasaran yang secara tidak pemasaran dan penjualan industri

Analisis strategi bauran pemasaran....

Abdul haris mana perluasan pangsa pasar pada saat ini yang diterapkan oleh industri masih sangat minim yang memengaruhi kurangnya penjualan. Hal ini disebabkan kurangnya perhitungan tentang seberapa penting perluasan pemasaran baik dalam negeri khususnya antara perusahaan yang bergerak dibidang yang sama maupun perluasan pemasaran di luar negeri. Dengan demikian peningkatan maupun penurunan tingat volume produksi dapat dilihat pada tabel 4 berikut :

Tabel 4

Volume Penjualan Kapal Pada Pt. Industri Kapal Indonesia (Persero) Makassar Tahun 2012 - 2016

\begin{tabular}{ll}
\hline Tahun & $\begin{array}{l}\text { Volume Penjualan } \\
\text { perusahaan (Rp) }\end{array}$
\end{tabular}

Volume Penjualan

Industri Keseluruhan

(Rp)

\begin{tabular}{ll}
2012 & 36.997 .000 .000 \\
2013 & 61.969 .000 .000 \\
2014 & 88.784 .000 .000 \\
2015 & 54.915 .000 .000 \\
2016 & 133.699 .000 .000 \\
\hline
\end{tabular}

66.922.000.000

111.996 .000 .000

120.124 .000 .000

69.705 .000 .000

221.068.000.000

\section{Perkembangan (Persentase)}

67,35
7,25
$-41,97$
217,15

Dari data strategi pemasaran dan penjualan produk kapal di atas, dapat menunjukkan bahwa strategi pemaaran penjualan yang dilakukan oleh PT. Industri Kapal Indonesia (Persero) Makassar dari tahun 2012-2014 mengalami peningkatan yang cukup tinggi di mana tingkat penjualan mencapai $\quad 74,6 \%$ Terjadinya peningkatan disebabkan karena adanya stratifikasi konsumen dan strategi pemasaran yang dilakukan oleh pihak perusahaan baik dalam melakukan promosi dan peningkatan kualitas

\section{Analisis Perluasan Pangsa Pasar Perusahaan}

Untuk mempertahankan kelangsungan hidup perusahaan maka perusahaan harus mengadakan peluasan dan peningkatan penjualan secara signifikan agar tetap mampu bersaing dengan perusahaan sejenisnya di pasar yand merupakan salah satu tujuan dari perusahaan. Karena apabila perluasan pangsa pasar samakin lama semakin besar, maka perusahaan akan mempunyai posisi yang kuat dalam

produk dalam setiap produksinya, dalam hal ini dilakukan secara berkesinambungan mulai dari tahun 2012 sampai sekarang sehingga menunjang peningkatan penjualan dari tahun ke tahun.

Dengan demikian penjualan yang ditinjau dari kualitas produk yang dihasilkan dapat semakin meningkat sehingga keuntungan yang mampu diperoleh perusahaan semakin besar pula.

persaingan dengan perusahaan lain yang bergerak pada bidang yang sama. Begitupun sebaliknya jika perluasan pangsa pasar semakin kecil, berarti perusahaan akan kesulitan dalam memasarkan produk nantinya. Jadi perluasan pangsa pasar perusahaan adalah perbandingan antara penjualan perusahaan dengan penjualan perusahaan sacara keseluruhan. Oleh karena itu perluasan pangsa pasar perusahaan merupakan kriteria atau ukuran keberhasilan manajemen perusahaan dalam pencapaian kegiatan 
Analisis strategi bauran pemasaran....

Abdul haris

pemasaran. Kegiatan pemasaran dilakukan untuk meningkatkan perluasan pangsa pasar dan harus diarahkan kepada pelanggan atau konsumen guna menarik dan mendorong mereka untuk melakukan pembelian.

Oleh karena itu PT. Industri Kapal Indonesia (Persero) Makassar menjalankan strategi pemasaran sehingga mampu mencapai target yang diinginkan dan penjualan semakin

Tabel 5

Volume Penjualan Kapal Yang Ditinjau Dari Perluasan Pangsa Pasar Pada PT. Industri Kapal Indonesia (Persero) Makassar Tahun 2012 - 2016

\begin{tabular}{cccc}
\hline Tahun & Penjualan Perusahaan & $\begin{array}{c}\text { Volume Penjualan } \\
\text { Penjualan Industri } \\
\text { Keseluruhan }\end{array}$ & Volume Penjualan \\
2012 & 36.969 .000 .000 & 66.922 .000 .000 & 55,24 \\
2013 & 61.969 .000 .000 & 111.996 .000 .000 & 55,33 \\
2014 & 88.784 .000 .000 & 120.124 .000 .000 & 73,91 \\
2015 & 54.915 .000 .000 & 69.705 .000 .000 & 78,78 \\
2016 & 133.699 .000 .000 & 221.068 .000 .000 & 60,48 \\
\hline
\end{tabular}

Sumber data : PT. Industri Kapal Indonesia dan Departemen Industri Makassar

Dari data di atas terlihat dengan adanya penurunan penjualan perusahaan pada tahun 2015 sebesar 54.915.000.000 yang mana mempengaruhi penjualan industri secara keseluruhan, hal ini disebabkan oleh penjualan kapal pada PT. Industri Kapal Indonesia (persero) Makassar masih dalam tahap pemantapan promosi dan pengaruh harga bahan baku yang penerapannya lebih cenderung diminimalkan, karena digunakan sebagai dana cadangan perusahaan sebagai dampak dari perubahan nilai mata uang. Dengan demikian perusahaan mampu bertahan dalam persaingan pasar yang lebih mengandalkan modal dalam membangun suatu perusahaan.

Di dalam menganalisa dan menghitung besarnya perluasan pangsa pasar yang diperoleh oleh perusahaan digunakan rumus sebagai berikut :

$\mathbf{M S}=\frac{\sum P p}{\sum P i} \times 100 \%$

Berdasarkan pada rumus tersebut di atas, maka perhitungan perluasan pangsa pasar perusahaan selama lima tahun terakhir adalah sebagai berikut :

Tahun 2012

$$
\begin{aligned}
& =\frac{36.994 .000 .000}{66.922 .000 .000} \times 100 \% \\
& =\quad 59,762 \% \\
& =\frac{61.969 .000 .000}{111.996 .000 .000} \times 100 \% \\
& =55,331 \%
\end{aligned}
$$


Analisis strategi bauran pemasaran....

$\begin{array}{ll}\text { Tahun } 2014 & =\frac{88.784 .000 .000}{120.124 .000 .000} \times 100 \% \\ & =\frac{73,901 \%}{69.705 .000 .000} \times 100 \% \\ \text { Tahun } 2015 & =\frac{78,782 \%}{221.068 .000 .000} \times 100 \% \\ \text { Tahun } 2016 & =60,478 \%\end{array}$

Abdul haris

Berdasarkan data tabel di atas maka hasil perhitungan perluasan pangsa pasar selama 5 (lima) tahun terakhir menunjukkan bahwa dari tahun 2012 besarnya perluasan pangsa pasar yang dicapai perusahaan $59,762 \%$, tahun 2013 besarnya 55,331\% , tahun 2014 sebesar 73,910\%, sedangkan pada tahun 2015 sebesar 78,782\% dan pada tahun 2016 sebesar 60,478 \%. Jadi dengan demikian besarnya perluasan pangsa pasar yang dicapai oleh perusahaan sangatlah tergantung pada persediaan produk kapal yang mana

\section{KESIMPULAN}

Berdasarkan pembahasan maka penulis dapat menarik kesimpulan sebagai berikut :

1. Adanya penurunan penjualan pada tahun 2015 sebesar 54.915.000.000 yang mana mempengaruhi penjualan industri keseluruhan, hal ini disebabkan oleh masih belum maksimalnya promosi yang digunakan serta karena di gunakannya sebahagian dana produksi sebagai dana cadangan perusahaan dalam mengantisipasi kenaikan bahan baku dan penurunan nilai mata uang, dengan demikian nantinya akan dapat memenuhi permintaan konsumen pada saat dibutuhkan.

Oleh sebab itu dengan adanya hal tersebut di atas, maka dapatlah disimpulkan bahwa PT. Industri Kapal Indonesia (pesero) Makassar mempunyai posisi yang cukup kuat dan strategis di pasaran terhadap kemampuan untuk meraih pangsa pasar, hal ini dapat di lihat dari perolehan persentasi yang dari tahun ke tahun selalu melebihi $50 \%$.

perusahaan mengalami penurunan penjualan.

2. Besarnya perluasan pangsa pasar yang dicapai oleh perusahaan sangat tergantung pada persediaan produk kapal yang mana nantinya akan memenuhi permintaan konsumen pada saat dibutuhkan. Oleh karena itu PT. Industri Kapal Indonesia (Persero) Makassar mempunyai posisi yang cukup kuat dan sangat strategis di pasaran terhadap kemampuan untuk meraih pasar.

3. Untuk mempertahankan kelangsungan hidup perusahaan maka perusahaan harus mengadakan peningkatan penjualan dan promosi produk 
secara intensif agar mampu bersaing di pasar yang akan menjadi tujuannya. Karena dengan semakin besarnya perluasan pangsa pasar maka perusahaan mampu menguasai dan mengendalikan pasar. Oleh karena itu perluasan pangsa pasar perusahaan merupakan kriteria ataupun ukuran dalam

\section{DAFTAR PUSTAKA}

A.J Sihotang. Dkk. 1997. Manajemen Pemasaran. Penerbit CV. Lola Karya Medan. Medan

Angipora. 1999. Dasar-dasar Pemasaran. Penerbit PT. Grafindo Persada. Jakarta.

Assauri. 1999. Manajemen Pemasaran. Dasar Konsep dan Strategi. Penerbit PT. Raja Grafindo Persada. Jakarta

Asri. 1993. Strategi dan Program Manajemen Pemasaran. Penerbit PT. Erlangga. Jakarta

Irwan. 1999. Pemasaran; Prinsip dan Kasus, Edisi 2. Penerbit BPFEUGM. Yogyakarta

Kusumadma. $1998 . \quad$ Keputusan Pemasaran. Cetakan pertama. Edisi pertama. Penerbit PT. Erlangga. Yogyakarta

Kotler Philip. 1997. Manajemen Pemasaran ( Marketing Management) Analisis, Perencanaan, Implementasi dan Kontrol. Edisi Bahsa Indonesia, Jilid dua, alih Bahasa; Hendar Teguh dan Ronny A.Rusli. Penerbit PT. Miurtigraha Perkasa Dinamika Prenhallindo. Jakarta

Kotler Philip dan Amstrong Gary. 1997. Principles of Marketing. (Terjemahaan : Alexander Sindoro) : Dasar-dasar Pemasaran. Penerbit PT. Miurtigraha Perkasa Dinamika Prenhallindo. Jakarta

Kotler Phiilip. 1998. Manajemen Pemasaran, Analisis Perencanaa
Analisis strategi bauran pemasaran.... Abdul haris keberhasilan manajemen perusahaan dalam mencapai kegiatan pemasaran yang dilaksanakan untuk meningkatkan perluasan pangsa pasar dan harus diarahkan kepada pelanggan atau konsumen guna menarik dan mendorong mereka untuk melakukan pembelian.

dan Pengendalian. Ctakan ketujuh. Edisi kedelapan, Penerbit PT. Miurtigraha Perkasa Dinamika Prenhallindo. Jakarta

Kuswara. $1995 . \quad$ Dasar-dasar Manajemen Pemasran. Penerbit PT. Mandar Maju. Bandung

Nitsemito. 1994. Manajemen Pemasaran. Cetakan keenam. Penerbit PT. Ghaliah Indonesia. Jakarta

Sudarmo. 2000. Manajemen Pemasaran. Edisi pertama. Cetakan keempat. Penerbit BPFEUGM. Yogyakarta

Stanton. 1991. Dasar-dasar Manjemen. Mc.Graw Hill Book Company. Singapore

Swastha. 1990. Azas-azas Marketing. Edisi ketujuh. Penerbit Liberty. Yogyakarta

1995. Azas-azas Marketing. Edisi ketiga. Penerbit Akademi Keuangan dan Bisinis. Jakarta .. 1996. Manajemen Pemasaran Modern. Azas-azas Marketing. Penerbit Liberty. Yogyakarta 